Marquette University

e-Publications@Marquette

Economics Faculty Research and Publications

Economics, Department of

5-1-2014

\title{
Transportation Costs and U.S. Manufacturing FDI
}

Joseph P. Daniels

Marquette University, joseph.daniels@marquette.edu

Marc von der Ruhr

St. Norbert College

Accepted version. Review of International Economics, Vol. 22, No. 2 (May 2014): 299-309. DOI. (C) 2011 Wiley. Used with permission. 


\title{
Transportation Costs and U.S. Manufacturing FDI
}

\author{
Joseph P. Daniels \\ Visiting Fulbright Chair of Governance and Public Policy \\ McMaster University \\ Professor of Economics \\ Marquette University \\ and \\ Marc von der Ruhr \\ Professor and Chair \\ Department of Economics \\ St. Norbert College
}

Corresponding author:

Joseph Daniels, Department of Economics, College of Business Administration, Marquette University, Milwaukee WI 53201-1881

joseph.daniels@mu.edu

(414) 288-3368 


\title{
Transportation Costs and U.S. Manufacturing FDI
}

\begin{abstract}
In empirical models of foreign direct investment (FDI), distance is most often used to proxy for transportation costs, and other pure-trade costs. However, real transportation costs show considerable fluctuation over the last two decades. The contribution of this work is to explicitly control for transportation costs and thereby better understand their impact on FDI. We explore the impact of shipping costs on total U.S. FDI stocks and manufacturing stocks abroad in a Hausman-Taylor model that controls for endogeneity and allows for time-invariant variables such as distance,. We find that transportation costs have a positive and statistically significant relationship with U.S. total and manufacturing FDI with horizontal MNE activity.
\end{abstract}




\section{Transportation Costs and U.S. Manufacturing FDI}

\section{Introduction}

Since its introduction to the study of international trade by Tinbergen (1963), the gravity model continues to serve as the primary approach in many empirical studies. Combes, et al. (2008) trace social scientists' use of the gravity model as far back as the late 1800 s to early 1900 s as a tool for examining first, migration flows and second, consumer shopping behavior. More recently the gravity model has been extensively employed to empirically investigate patterns of trade and foreign direct investment (FDI). For these issues, the empirical relevance of the gravity model is appealing in its basic modeling of spatial relationships.

As with any economic model, however, the gravity model has both its theoretical and empirical shortcomings. Researchers typically consider distance, the key spatial variable of the model, as capturing a wide array of trade, transportation, and information costs. Focusing specifically on distance, Combes et al. (p. 107) argue that “... in the gravity model, distance is nothing more than an aggregate of variables influencing trade between countries, which hides other far more complex phenomena. Distance, therefore, has the status of a black box..."

Nonetheless, as applied to patterns of international trade, distance is assumed to primarily, but not exclusively, reflect transaction and transportation costs, while applied to FDI it is assumed to reflect the costs of exporting but also costs associated with monitoring and coordinating firm activities (along the same lines as language and cultural differences), and fixed costs of plant set up. Egger and Pfaffermayr (2004) contend that in the case of horizontal FDI, trade and FDI are substitutes in regard to transportation costs and, therefore, distance should have a negative impact on trade and a positive impact on FDI. For vertical FDI, the impact of distance is ambiguous as foreign-owned plants tend to engage in both production and trade. 
Given that the preponderance of FDI occurs between advanced economies, the authors suggest it is likely that horizontal FDI dominates in an empirical model.

More recently, researchers have questioned whether geographical distance should matter at all; arguing that advances in telecommunications and declining transportation costs should mitigate the impact of distance on both trade and FDI. It is clear that there have been rapid advances in telecommunications and associated declines in communication costs. Further, advances in shipping - such as the introduction of container shipping, as well as reduced weight (per dollar value) of products shipped - have led to declines in transportation costs.

However, other factors have the opposite effect, as occasionally congested ports and higher fuel costs drive up sea and air shipping costs. Indeed sea-freight costs rapidly increased in the late 1990s and early 2000s before dramatically declining during the global recession of the late 2000s, and eventually reaching a twenty-five year low in 2012. Air-freight costs also shot up dramatically along with sea-freight costs but, in contrast, began to rise again after the recession. Assuming that shipping and air freight costs have steadily declined and are now irrelevant would, therefore, be incorrect. In fact, producers face both volatile sea-freight and air-freight costs that may or may not correlate over time. As a result, empirical studies that examine distance over time as a measure of pure trade costs without explicitly controlling for changes in transportation costs may well show ambiguous or counterintuitive results. Likewise, studies that ignore transportation costs may be overlooking an important determinant of FDI as FDI can be a strategy to hedge against volatility in shipping costs.

Our objective here is to provide additional evidence on the role of transportation costs in empirical studies of the pattern of FDI. Specifically, we focus on U.S. manufacturing FDI to fifty-three countries over a twenty-six year period. Our primary contribution is two-fold. First, 
we introduce a direct measure of average transportation costs using measures of sea-freight costs and air-freight costs. Second, our main empirical results are derived from a Hausman-Taylor model, which allows us to maintain time-invariant variables such as distance in the model (see Egger and Pfaffermayr 2004 for an earlier application of this model to FDI patterns). Our main finding is that sea-freight and air-freight costs are positive and economically and statistically significant variables in a model of U.S. manufacturing FDI.

The following section provides a discussion of the treatment of transport costs in the literature, offers a simple model of the impact of these costs on the strategy of the international firm, and describes the behavior of transportation costs since 1985. In Section 3 we describe the data used in the empirical analysis. Section 4 discusses the empirical modeling and Section 5 provides the empirical results and robustness tests. Section 6 offers a conclusion and suggestions for future research.

\section{Distance and Transportation Costs}

Obstfeld and Rogoff (2000) claim that the six major "puzzles" in macroeconomics result primarily from international trade costs in goods. They point out that trade costs include not only transportation costs but other policy and non-policy barriers that hinder international trade. In a review of the importance of trade costs for international trade, Anderson and van Wincoop (2004, p. 691) drive their point home in the opening sentence, stating that "The death of distance is exaggerated."

\subsection{Distance and the Gravity Model}

The role of distance in this context is very important as the gravity model continues to be the primary model of empirical analysis of trade and FDI. In the gravity model, distance proxies for 
a number of different costs including transport costs, transaction costs, and communication and cultural frictions. Hence, much of the empirical work continues to include distance as a determinant of both trade and FDI.

Focusing on the role of distance, Leamer and Levinshon (1995) are among the earliest authors to comment on the empirical robustness of the negative correlation between distance and trade flows. In contrast, Brun et al. (2005) examine trade data for 130 countries over the period of 1962 through 1996. They argue that transport costs declined over this period and show that the impact of distance (interacted with a time trend) declined over this period. Coe et al. (2007) find a decline in the role of distance on trade, arguing that the "stable" relationship of previous work was due to the improper treatment of zero observations in the data. Head et al. (2009) also find a significant but declining impact of distance on service trade.

Hummels (2007) focuses specifically on transportation costs, pointing out that the literature links the rapid rise of international trade in the first era of globalization to declines in shipping costs. He states that decreasing transportation costs may once again be a popular and plausible explanation of the rise in international trade during the second era of globalization while simultaneously countering this notion, pointing out that changes in transportation costs are very complex. Indeed the scarcity of data on transportation costs is one factor that hampers work on the distance effect. Studies that directly use transport cost data (for example Baier and Bergstrand 2001, Brun et al. 2005, Hummels and Lugovsky 2003, and Limão and Venables 2001) tend to use data covering a small sample of countries over a limited time period or much older time period.

In empirical studies on FDI, distance also plays an important, related, and yet different role. Specifically, distance can not only reflect the cost of exporting goods (and thus related to 
FDI decisions), but also fixed plant-setup and other investment costs, and information and communication costs associated with operations management. In the vast majority of studies that include distance, the relationship between distance and FDI is found to be negative (see Eicher $e t$ al. 2011, Blonigen 2005 and Blonigen and Piger 2011 for a summary of this and other determinants of FDI).

Egger and Pfaffermayer (2004), in contrast, argue that the impact of distance on FDI is $a$ priori ambiguous. A positive relationship would exist for horizontal FDI, in which a firm produces abroad rather than exports while an ambiguous relationship would result for vertical FDI as the foreign operation would both produce and export. Using a model of both FDI and trade, they find a positive relationship between distance and FDI stocks supporting the suggesting that horizontal FDI dominates in the data. Hummels (2007) provides a wealth of information on the cost of exporting goods along with the changing modes of transportation, roughly covering the period from 1950 to 2004 . His main points are that; manufactured goods are both the largest and fastest growing segment of global trade, over-land trucking is the main mode of transportation among contiguous nations, and air shipments represent a small portion of non-bulk trade, but are growing faster than sea shipping. The heaviest products travel by sea, but in the case of the United States, a fall in the weight-to-value ratio of exports increased opportunities to substitute between the two modes of shipping and led to a much greater proportion of goods shipped by air than the global average.

What is lacking in the literature to this point, however, is the explicit inclusion of transportation costs over a long time frame that includes the entirety of the 2000s. The reason this period is important, in additional to the significant FDI that occurred, is that transportation costs, specifically sea and air shipping costs, have not uniformly declined. Rather the period 
from the late 1990s through 2010 is marked by significant swings in sea and air transportation costs.

\subsection{Theoretical Framework}

To relate our discussion of the impact of shipping costs on the strategy of the international firm to produce at home or invest abroad, we employ an extended version of the models of Davies et al. (2007) and Egger and Pfaffermayr (2004), which have their roots in the work of Horstmann and Markusen (1992), and Markusen and Venables (1998). Because our focus is on the manufacturing sector, we consider horizontal activity of the international firm in the home economy, $h$, that produces its output in the home economy to serve the market of the home economy and chooses to export to, or produce in the foreign economy, $f$, in order to serve the market of the foreign economy. The unit labor requirement, $c$, to produce the good, $x$, is identical in both the home and foreign economy ( $x_{h}$ and $x_{f}$ respectively). In additional to the unit labor cost, when producing in the home economy the firm faces fixed costs, $k_{h}$.

If the international firm chooses to produce the good in the home economy, $x_{f}$, and export it to the foreign economy, it faces (in additional to labor and fixed costs) iceberg-type transport costs, $t$, such that less than one exported unit of the good is available for sale in the foreign economy. This cost has a constant component - meaning here that it is relatively constant over time and does not depend on the distance between the home and foreign economy - that is specific to the foreign economy and depends on various items that include customs documents, financing, and insurance. ${ }^{1}$ The transport cost also has a component that depends on the distance and average shipping costs between the home and foreign economy. The total transport cost is

\footnotetext{
1 The World Bank and PricewaterhouseCoopers consider trading costs in the Doing Business report. The costs considered include time and explicit costs for customs and border agencies, inland transportation, and port and terminal handling. This cost would be an interesting addition but the series only began 2006 and offers too few data points at this time.
} 
expressed as $t=t_{0}+\eta d_{h f}$, where $t_{0}$ is the constant component, $d_{h f}$ is the distance between the home and the foreign economy, and $\eta$ is the per-mile-average unit cost associated with shipping the product abroad. Though the distance between two economies is constant, the per-mileaverage cost may change over time.

If the international firm chooses to produce the product in the foreign economy, it does not face transport costs, but does face fixed costs, $k_{f}$. It is assumed that these costs are also similar to iceberg costs in that the firm must transfer an additional amount of capital to the foreign economy in addition to that required in the home economy in order to produce the same unit of output. These additional fixed costs also have a constant component specific to the foreign economy that does not depend on distance and a component that depends on the distance between the home and foreign economy. The total fixed costs associated with producing in the foreign economy are expressed as $k_{f}=k_{h}\left(1+\gamma_{0}+\rho d_{h f}\right)$, where $\rho$ is the per-mile-average unit fixed cost which conditions how distance drives up fixed costs. It is assumed that the constant component of the average fixed cost of producing in the foreign economy is greater in value than the constant component of the transportation cost, $\left(k_{h} / x_{f}\right)\left(1+\gamma_{0}\right)>t_{0}$. The rationale behind this is that if distance were completely irrelevant $\left(d_{h f}=0\right)$, we assume that it is more profitable for the international firm to be an exporter $(E X)$ than becoming a multinational enterprise $(M E)$. It follows that the parameters $\eta$ and $\rho$ determine how distance influences the relative importance of transport costs versus fixed costs of producing in the foreign economy. A second assumption is that the per-mile-average unit cost associated with shipping good $x_{f}$ to the foreign economy is greater than the per-mile-average unit fixed cost, $\eta>\left(k_{h} / x_{f}\right) \rho$. In words, we assume that for the 
manufacturing sector the shipping costs that vary with distance are more important (larger in value) than the information and management costs that vary with distance.

Following the literature, and specifically Davies et al. (2007), demand follows a constant elasticity of substitution form constrained by total income. Based on first-order conditions the inverse demands for goods $x_{h}$ and $x_{f}$ are:

$$
p_{h}=a-D_{h}, \quad \text { and } \quad p_{f}=a-D_{f} \text {, }
$$

In order to combine together all of the aspects described above, first consider the profits of the purely domestic firm, $\pi_{h}^{D M}$, in the home country,

$$
\pi_{h}^{D M}=\left(p_{h}-c\right) x_{h}-k_{h}
$$

Following equations (1) and (2), we now express the profits of the international firm depending on whether it exports or operates as a multinational enterprise as:

$$
\pi_{h}^{E X, M E}\left\{\begin{array}{ll}
\pi_{h}^{E X}=\left(p_{h}-c\right) x_{h}-k_{h}+\left(p_{f}-c-t\right) x_{f} & \text { if } \pi_{h}^{E X}>\pi_{h}^{M E} \\
\pi_{h}^{M E}=\left(p_{h}-c\right) x_{h}-k_{h}+\left(p_{f}-c\right) x_{f}-k_{f} & \text { if } \pi_{h}^{E X}<\pi_{h}^{M E}
\end{array} .\right.
$$

Expanding the parameterization of the transport and fixed costs yields:

$$
\pi_{h}^{E X, M E}\left\{\begin{array}{ll}
\pi_{h}^{E X}=\left(p_{h}-c\right) x_{h}-k_{h}+\left(p_{f}-c-t_{0}-\eta d_{h f}\right) x_{f} & \text { if } \pi_{h}^{E X}>\pi_{h}^{M E} \\
\pi_{h}^{M E}=\left(p_{h}-c\right) x_{h}-k_{h}+\left(p_{f}-c\right) x_{f}-k_{h}\left(1+\gamma_{0}+\rho d_{h f}\right) & \text { if } \pi_{h}^{E X}<\pi_{h}^{M E}
\end{array} .\right.
$$

We can consider the choice of the firm by subtracting the profit from exporting from the profit from producing in the foreign economy, $\pi_{h}^{M E}-\pi_{h}^{E X}$, and evaluating this difference for given values of $\rho$ and $\eta$, denoted $\rho_{0}$ and $\eta_{0}$. Begin with case where distance is irrelevant, $d_{h f}=0$. In this case the profit difference is $-\left[\left(k_{h} / x_{f}\right)\left(1+\gamma_{0}\right)-t_{0}\right]$, which is negative by assumption. Next, the tipping point, or the point at which the firm is indifferent between the two strategies is where 
distance yields a value of zero for the profit difference, and occurs where distance equals the positive ratio, denoted $\bar{d}_{h f}$,

$$
\bar{d}_{h f}=\frac{\left[\left(k_{h} / x_{f}\right)\left(1+\gamma_{0}\right)-t_{0}\right]}{\eta_{0}-\left(k_{h} / x_{f}\right) \rho_{0}} .
$$

If the distance of a particular foreign market exceeds this value, the firm finds it more profitable to produce in the foreign economy than to export. If $\eta$ is allowed to vary from $\eta_{0}$, we can consider the derivative of (5) with respect to $\eta$ which is negative,

$\partial \bar{d}_{h f} / \partial \eta=-\frac{\left[\left(k_{h} / x_{f}\right)\left(1+\gamma_{0}\right)-t_{0}\right]}{\left[\eta_{0}-\left(k_{h} / x_{f}\right) \rho_{0}\right]^{2}}<0$, meaning that as the per-mile-average unit shipping cost

rises, the international firm finds it profitable to become a $M E$ at shorter and shorter distances.

These outcomes are displayed in Figure (1), which borrows from Davies et al., (Figure 1, page 33).

\section{[Figure 1 Here]}

The difference between the profit associated with the $M E$ strategy and the $E X$ strategy is plotted on the vertical axis. Below the horizontal axis the international firm finds it more profitable to export to the foreign economy and above the vertical axis it is more profitable to produce in the foreign economy. The point where distance is irrelevant and the tipping point as described above are illustrated on the vertical and horizontal axis respectively. The solid line illustrates the range of distance where, for a given per-mile-average shipping cost, $\eta_{0}$, the firm will choose to export and the range of distance where it will choose to produce in the foreign economy. The dashed line illustrates how theses ranges change as the per-mile-average shipping cost rises to $\eta_{1}$. And 
so, for the international firm engaged in horizontal activity an increase in shipping costs beyond a particular threshold induces the firm to choose a $M E$ strategy over the $E X$ strategy and, hence, FDI is expected to rise.

\subsection{Measuring Shipping Costs}

We now consider how to include explicit controls for average shipping costs and distance in an empirical model. In this study we use separate measures for sea and air shipping. The Baltic Dry index is used as a measure of average sea-shipping costs while the spot price of jet fuel (ARA) is used as a measure of average air-shipping costs. ${ }^{2}$ Both measures are taken from Bloomberg Data Services.

Figure 2 illustrates the Baltic Dry Index and the index for the spot price of jet fuel (to put the two on a comparable basis, the spot price of jet fuel is multiplied by ten in the figure). As the figure shows, the two indexes track closely (with a simple correlation coefficient of 0.67 ). In addition, Figure 2 provides a value-of-shipment weighted average of the two series. This series is created by using the value-of-shipment data on U.S. exports derived from Hummels (2007) and the U.S. Department of Transportation's Commodity Flows Survey (various years). ${ }^{3}$

\section{[Figure 2 Here]}

As Figure 2 shows, both measures had a remarkable degree of stability (on an annual basis) from 1985 through 2001. From October 2001 to May 2008, however, the Baltic Dry Index

\footnotetext{
2 The Baltic Dry Index includes a wide variety of ships and routes, including bulk cargo. An alternative index, the HARPEX index by Harper Petersen focuses specifically on container shipping (and is admittedly a preferred index to use for examining manufacturing trade). Unfortunately this index only began in 2006 . There is, however, a close correlation between the two measures (Wynne 2009) from 2006 to 2010. Regarding air freight costs, the U.S. Bureau of Labor Statistics recently developed the Export Air Freight Index as a measure of air cargo transportation costs. Unfortunately, the index only covers 1996 onward and is not available for every year. The spot price of jet fuel has a very high and positive correlation with this index and is used as a proxy measure for average air-shipping costs.

${ }^{3}$ The Baltic Dry Index and the index of the spot price of jet fuel were first benchmarked at 1985=100. The value-ofshipment data is available on a five-year basis. The missing years between observations were filled in on a linear basis.
} 
increased over 1,200 percent while Jet Fuel increased over 500 percent. After 2002 both series display not only a significant rise and fall, but also increased variability. From 1985 to 2001 as compared to 2001 to 2010, the (monthly) standard deviation of the Baltic Dry index increased by over 580 percent and by more than 400 percent for Jet Fuel. The data show that despite advances in the transportation sector, global transportation costs have not uniformly declined over the modern era of globalization. Hummels (2007) argues that technological advances are offset by adverse supply shocks. As a result, the figure shows that these costs have periods of significant increase and decline as well as an increase in variability.

\section{Data and Data Transformation}

To explore the role of transportation costs, we employ a model derived from the basic gravity equation and include explanatory variables suggested by the existing literature on FDI (see specifically Blonigen 2005, Eicher at al. 2011, and Bonigen and Piger 2011 for summaries). Our empirical analysis considers total U.S. FDI stocks, manufacturing FDI stocks, and service stocks. The sample period, driven by data availability of these stocks and the key transportation cost measures, covers annual data from 1985 through 2010, across 53 countries. Table 1 provides a list of all the countries in the sample.

\section{[Table 1 Here]}

\subsection{Data Description}

Our dependent variables are total U.S. FDI stocks, manufacturing stocks, and service stocks as published by the U.S. Bureau of Economic Analysis (BEA). These are converted to real stocks using the Nonresidential Gross Private Domestic Investment Deflator, also from the BEA. These measures are then logged. We include other standard variables found in the literature described 
in the previous section. The log of real GDP per capita, population, trade openness expressed as the total of exports and imports as a percentage of GDP, and domestic credit to the private sector as a percentage of GDP are from the World Development Indictors of the World Bank. The log of distance is taken from the CEPII GeoDist Database, from which we specifically use the bilateral distances between the largest cities of the U.S. and the host country, with the inter-city distances weighted by the share of the city in overall population, following Head, et al., (2010).

Time-varying dummy variables are included for bilateral investment treaties, trade agreements, and tax treaties, and are derived from information at the U.S. Trade Compliance Center and the U.S. Internal Revenue Service. Time-invariant dummy variables for adjacency and land-locked economies are also included. The log of the real exchange rate between the U.S. dollar and the currency of the host country (expressed as U.S. dollar/host currency so that an increase in the value of indicates a real appreciation of the host country currency relative to the U.S. dollar) is calculated using the annual average exchange value and CPI data from the International Monetary Fund International Financial Statistics.

As stated earlier, to reflect average transportation costs, we include the Baltic Dry Index to measure the cost of sea freight (which, in spite of its name, actually measures average global shipping costs via the 26 major shipping routes) and the spot price of jet fuel as a proxy measure of air transportation costs. Because some firms may be able to substitute among these two modes of shipping, we calculate a weighted-average value using value-of-shipment data. The weightedaverage measure is deflated by the U.S. producer price index to reflect real transportation costs and is then interacted with the distance measure to represent the cost component $\eta d_{h f}$ of the theoretical model.

To capture information costs and capabilities we include the growth of (land-line) phone 
subscriptions and mobile phone subscriptions per 100 people from the World Development Indicators as a proxy measure of advances in telecommunications. ${ }^{4}$ Finally, we include Geert Hofstede's index of national culture to reflect management and monitoring frictions that arise from enterprises owned and operated in different cultural environments. This index measures the difference in culture of the host country relative to the United States along four different dimensions; power distance, individualism versus collectivism, masculinity versus femininity, and uncertainty avoidance. A single measure is created by averaging the squared difference of each dimension with that of the United States (a value of 100 as the United States is the benchmark). ${ }^{5}$ Hence, the larger the value, the greater is the cultural distance between the United States and the host country. Table 2 provides summary statistics for all (non-dummy) variables used in the analysis.

[Table 2 Here]

\subsection{Variance of FDI Stocks}

In addition to the standard summary statistics, Table 2 also provides estimates of between and within variances. For example, the standard deviation of total FDI stocks over the entire sample of (N) 1,302 observations for (n) 53 countries, with an average number of 24.5 observations of per country $(\overline{\mathrm{T}})$, is 52514.24 . The between measure (38351.04) reflects variability across the cross-sections and is the standard deviation of the mean value of the variable for each crosssection. The within measure (35342.99) reflects the average variability across time for each cross section. ${ }^{6}$ These variance estimates indicate that variability both across countries and across time

\footnotetext{
${ }^{4}$ Recently authors such as Hattari and Rajan (2008), Stein and Daude (2007), and Marjit (2007) use time zones as a determinant of FDI flows. This applies primarily to the service sector where technology allows services to be transported quickly. As a robustness test time zones were controlled for and found to be insignificant.

${ }^{5}$ More information on national culture can be found at Hofstede's website at geert-hofstede.com.

${ }^{6}$ The within estimate is the sum of the sum of squares, where for country $i$ the squared deviation of observation $x_{i}$ from the sum of the mean for the country $i\left(\bar{x}_{i}\right)$ plus the overall sample mean $\bar{x}$ to reduce scale differences.
} 
are relatively equally important.

In contrast, the within standard deviation for distance is zero as distance is time invariant while the between standard deviation for the weighted-average transportation cost is zero as this is an average measures and does not differ over cross-sections. Our objective here is employ a variable that reflects both the within and between variability aspects of transportation costs. Distance, therefore, is interacted with the weighted-average shipping cost to generate a countryspecific time-varying estimate of U.S. export costs to the host country which accounts for differences both within and between cross-sections.

\section{Empirical Model}

Our primary goal is to understand the relationship that might exist between transportation costs and manufacturing FDI. In a gravity model this is usually implicit in the distance term. An underlying objective is to also investigate the remaining role of distance in a gravity model of FDI when explicitly controlling for transportation costs, as well as other variables the distance term might proxy for, such as cultural distance. Hence, our empirical model includes both timevariant and time-invariant variables. Equation 1 below represents the base empirical model:

$$
y_{i t}=\beta_{1} X_{1 i t}+\Gamma_{1} Z_{1 i}+\mu_{i}+\varepsilon_{i t}
$$

where $\mathrm{X}_{1 \mathrm{it}}$ is a vector of time-varying (TV) variables and $\mathrm{Z}_{1 \mathrm{i}}$ is a vector of time-invariant (TI) variables. Both $\mathrm{X}_{1 \mathrm{it}}$ and $\mathrm{Z}_{1 \mathrm{i}}$ are initially assumed to be uncorrelated with both $\mu_{\mathrm{i}}$, the unobserved individual effects, and $\varepsilon_{\mathrm{it}}$, the random error.

Our analysis begins with a random effects model (REM). Next a fixed-effects model (FEM) is estimated and the Hausman test is used to test between the two models. Across all three models the Hausman test rejects the null that the REM estimates are consistent (that is, that the 
REM properly models the individual-level effects). Because a FEM model mean-differences the data, it cannot be used to explore the individual effects of important time-invariant variables of interest such as geographical and cultural distance that otherwise would be perfectly collinear with the country-level fixed effects. We therefore consider a Hausman-Taylor model (HTM), which is described next.

\subsection{Hausman-Taylor Model}

Baltagi (2008, p. 141) suggests a two-step series of tests where the REM is first tested against the FEM. If the REM is rejected, then a Hausman-Taylor model - which addresses the potential correlation among the independent variables and the panel-level random effect - is tested against the FEM. If the HTM is not rejected, then one can use the HTM while retaining interesting timeinvariant independent variables and yet still generate consistent estimates.

Using the notation and language of Egger and Pfaffermayr (2004), the HTM distinguishes between the TV variables that are exogenous and uncorrelated with both $\mu_{\mathrm{i}}$ and $\varepsilon_{\mathrm{it}}$ (doubly exogenous) and the TV variables that are correlated with $\mu_{\mathrm{i}}$ but not with $\varepsilon_{\mathrm{it}}$ (singly exogenous). Likewise the HTM distinguishes between the time-invariant TI variables that are exogenous and uncorrelated with both $\mu_{\mathrm{i}}$ and $\varepsilon_{\mathrm{it}}$ (doubly exogenous) and the TI variables that are correlated with $\mu_{\mathrm{i}}$ but not correlated with $\varepsilon_{\mathrm{it}}$ (singly exogenous). The regression model then becomes:

$$
y_{i t}=\beta_{1} X_{1 i t}+\beta_{2} X_{2 i t}+\Gamma_{1} Z_{1 i}+\Gamma_{2} Z_{2 i}+\mu_{i}+\varepsilon_{i t}
$$

for $i=1, \ldots, 53$ cross sections and $t=1, \ldots, 26$ years, where the $\mathrm{X}_{1 \text { it }}$ are doubly-exogenous TV variables, $Z_{1 \mathrm{i}}$ are doubly-exogenous $\mathrm{TI}$ variables, $\mathrm{X}_{2 \mathrm{it}}$ are singly-exogenous $\mathrm{TV}$ variables, and $\mathrm{Z}_{2 \mathrm{i}}$ are singly-exogenous TI variables.

The first step of the Hausman-Taylor model (see Greene, 2003) is to run the within 
estimator on equation (9) to obtain a consistent estimator of $\sigma_{\varepsilon}$. Second, the residuals from the within estimator are averaged over time and then regressed on the time invariant variables $\left(\mathrm{Z}_{1 \mathrm{i}}\right.$ and $\mathrm{Z}_{2 \mathrm{i}}$ ) with $\mathrm{Z}_{2 \mathrm{i}}$ instrumented by $\mathrm{X}_{1 \mathrm{i}}$. From this regression one obtains a consistent estimator of $\sigma^{2}$, where $\sigma^{2}=\sigma_{\mu}^{2}+\sigma_{\varepsilon}^{2} / T_{i}$, where $T_{i}$ is the number of observations for the cross-section. This estimator is then used to derive $T_{i} \sigma_{\mu}^{2}=T_{i} \sigma^{2}-\sigma_{\varepsilon}^{2}$. These values are used to generate the weight for GLS estimation, $\theta=1-\sqrt{\frac{\sigma_{\varepsilon}^{2}}{\sigma_{\varepsilon}^{2}+T_{i} \sigma_{\mu}^{2}}}$. Our estimated weight $\hat{\theta}$ is used to transform equation (7) as:

$$
y_{i t}-\hat{\theta} \bar{y}_{i}=\beta_{1}\left(X_{1 i t}-\hat{\theta} \bar{X}_{1 i}\right)+\beta_{2}\left(X_{2 i t}-\hat{\theta} \bar{X}_{2 i}\right)+\Gamma_{1} \hat{\theta} Z_{1 i}+\Gamma_{2} \hat{\theta} Z_{2 i}+\hat{\theta} \varepsilon_{1 i t}
$$

Note that the TI variables are the average for the cross section. In equation (10), the $\bar{X}_{1 \mathrm{i}}$ are used to instrument for $Z_{2 i}$. In words, equation (8) represents the weighted instrument-variable estimator. Overall, or in total, the $\mathrm{X}_{1 \mathrm{it}}, \mathrm{X}_{2 \mathrm{it}}$, and $\mathrm{Z}_{1 \mathrm{i}}$ are all used as within-model instruments.

\subsection{Categorization of Variables}

The categorization of the doubly-exogenous and singly-exogenous variables represents a key aspect of applying the Hausman-Taylor estimator. Following Egger and Pfaffermayr (2004), in this application a singly exogenous variable would correlate with the specific two-way or bilateral relationship. Distance of a host country to the U.S., for example, reflects a specific bilateral characteristic, or pair effect, and is therefore likely to correlate with the unobserved time-consistent $\mu i$. Following this, population growth, per capita GDP, size similarity, growth of phone subscriptions, credit to the private sector, and trade openness are treated as TV doublyexogenous variables while bilateral investment, trade, and tax treaties, the log of the real exchange rate, and the log of shipping costs (interacted with distance) are treated as singly- 
exogenous TV variables. ${ }^{7}$ The dummy variable for land-locked countries is treated as a doublyexogenous TI variable while cultural distance, geographical distance, and adjacency are treated as singly-exogenous TI variables. In order to properly implement this model, it is important that: (1) the number of doubly-exogenous TV variables, $X_{1 i t}$, equal or exceed the number of singlyexogenous TI variables, $\mathrm{Z}_{1 \mathrm{i}}$, and (2) there is some correlation among the $\mathrm{X}_{1 \text { it }}$ and $\mathrm{Z}_{2 \mathrm{i}}$ variables to serve as "within" model instruments.

For all model specifications, the Hausman test on the HTM versus the FEM did not reject the model specification given above over the FEM. In addition, the model coefficients of the FEM remain relatively unchanged with the application of this specification of the HTM (which can be seen later in Tables 3). The Sargan-Hansen tests statistic does not indicate that the models are over-identified. Hence, we settle on this specification of the HTM and the results, along with some robustness checks, are presented in the next section.

\section{Results}

Table 3 provides our empirical results. Note that all models include unreported year controls. ${ }^{8}$ The F test of joint significance of these controls is reported near the bottom of Table 3. Economic size similarity is significant in all models with a $p$-value of less than 10 percent in the FEM model for total stocks and less than 1 percent in all other models. Phone subscriptions are negative and significant in the models for manufacturing and service stocks and the log of population is negative in the service stocks models. The sign of these two variables could well be due to phone subscriptions and population rising the fastest among developing nations for which the U.S. has less overall FDI activity. Note that the results for total stocks may differ from the

\footnotetext{
${ }^{7}$ Regarding size similarity, we follow Egger and Pfaffermayr and treat it as doubly-exogenous. We then test the model for overidentification.

${ }^{8}$ The data file and the Stata command files are available from the authors upon request.
} 
combined results of manufacturing and service stocks as total stocks include other important industries such as mining, utilities, agriculture and so on.

Bilateral investment treaties (BIT) are negative and significant in all the HTM models and tax treaties are positive and significant for service stocks. It is quite likely that the sign and significance of the BIT variable may be due to the pooling of developed and developing countries in this single variable. Because these treaties go well beyond the topic here, we refer the reader to Busse et al. (2010) for recent work on BITS and to Blonigen and Davies (2004) for an example of the problem with pooling dummy variables for developing and developed countries in an application on tax treaties.

The real exchange rate is positive and significant in the HTM for total stocks, implying that an appreciation of the host country's currency is associated with an increase in overall U.S. FDI activity in that country. Blonigen (1997 and 2005) concisely details the underlying theories on the exchange rate and FDI activity that postulate either that a host country appreciation will have no effect on FDI, a negative effect, or a positive effect. De Vita and Abbott (2007) argue that a rise in the value of the foreign currency motivates an investment into the foreign economy because the return on the investment will increase.

The interaction term of the value-of-shipment weighted-average transportation cost with distance is significant and positive in the models on total stocks and manufacturing stocks. The fixed effects estimates and HT estimates for shipping costs are very similar in magnitude and the estimated coefficients for total stocks and manufacturing stocks imply that at a given distance, a 1 percent increase in shipping costs leads to an approximate 0.20 percent and 0.16 percent increase in total stocks and manufacturing stocks respectively. As explained earlier, positive and significant values for the shipping costs are consistent with horizontal activity dominating 
vertical activity and, hence, a substitute relationship between trade and FDI. The interaction term is positive but insignificant in the models on service stocks. We would expect the type of shipping costs considered here to affect the manufacturing sector but not necessarily the service sector. Otherwise, the robust results described above may be reflecting some within-crosssection effect other than transportation costs. Note that distance by itself is insignificant in all three HTM models.

In addition to the models provided above, we also undertook a number of robustness checks. First, we ran models with both the sea-shipping and air-shipping costs interacted with distance in place of the weighted-average value interaction term and tested their joint significance. The two costs were jointly significant in the models for total stocks and manufacturing stocks. ${ }^{9}$ To account for potential agglomeration effects, we included the lag of the dependent variable in each model. In the HTM, the lag of the stock was treated as a TV singlyexogenous variable. Model fit improved slightly in all models and the results are very similar to those reported in Table 3.

\section{Conclusion}

In empirical models of FDI, distance is most often used to proxy for transportation costs, as well as other pure trade costs. Egger and Pfaffermayr (2004, p. 227), however, claim that “...the association of distance with pure trade costs is questionable." The contribution of this work is to provide an explicit control for transportation costs and thereby better understand their impact on manufacturing FDI. Using measures of sea-freight and air-freight costs we construct a value-ofshipment weighted average. This measure is included in a Hausman-Taylor model that controls

\footnotetext{
${ }^{9}$ Note that if any of the costs terms are entered without first interacting them with distance, then the year controls must be dropped as terms that vary only over time will be collinear with the year controls.
} 
for endogeneity and allows for time-invariant variables such as distance. This measure is positive and significant in models of total FDI stocks and manufacturing FDI stocks, indicating that shipping costs have a positive and significant relationship with U.S. manufacturing FDI. This suggests that these FDI stocks have a substitute relationship with trade flows consistent with horizontal MNE activity.

To understand the role of transportation costs better, it would be useful to include the variability of transportation costs that may be an important driver of FDI decisions. This will require higher frequency data to generate variance estimates. Likewise, labor cost differentials are another important factor influencing FDI, which also change over time. Perhaps future research could include these costs alongside shipping costs, though currently the cross-country data on labor costs is rather limited.

\section{References}

Anderson, James E. and Eric Van Wincoop. 2004. Trade Costs. Journal of Economic Literature XLII(September): 691-751.

Baier, Scott. L. and Jeffrey. H. Bergstrand. 2001. The Growth of World Trade: Tariffs, Transport Costs, and Income Similarity. Journal of International Economics 53(1): 1-27.

Baltagi, Badi H. 2008. Econometric Analysis of Panel Data: Fourth Edition. Chichester, UK: John Wiley and Sons.

Blonigen, Bruce A. and Jeremy Piger. January 2011. Determinants of Foreign Direct Investment. University of Oregon working paper.

Blonigen, Bruce A. 2005. A Review of the Empirical Literature on FDI Determinants. Atlantic Economic Journal, 33(4): 383-403.

Blonigen Bruce A., and Ronald B. Davies (2004). "The Effects of Bilateral Tax Treaties on U.S. FDI Activity," International Tax and Public Finance, 11(5), 601-622.

Blonigen, Bruce A. 1997. Firm Specific Assets and the Link between Exchange Rates and Foreign Direct Investment. American Economic Review 87: 447-65.

Brun, Jean-François, Céline Carrére, Patrick Guillaumont, and Jaime de Melo. 2005. Has Distance Died? Evidence from a Panel Gravity Model. World Bank Economic Review 19(1): 99-120.

Busse, Matthias, Jens Königer, and Peter Nunnenkamp. 2010. FDI Promotion through Bilateral Investment Treaties: More than a Bit? Review of World Economics, 146: 147-177.

Coe, Daid T., Arvind Subramanian, and Natalia T. Tamirisa. 2007. The Missing Globalization Puzzle: Evidence of the Declining Importance of Distance. IMF Staff Papers 54(1): 34-58. Combes, Pierre-Philippe, Thierry Mayer, and Jacques-François Thisse. 2008. Economic 
Geography: The Integration of Regions and Nations. Princeton: Princeton University Press. Cox, Nicholas J. 2007. Transformations: An Introduction.

http://fmwww.bc.edu/repec/bocode/t/transint.html

Davies, Ronald B, Harmut Egger, and Peter Egger. 2007. Tax Competition for International Producers and the Mode of Foreign Market Entry. Oxford University Centre for Business Taxation, Working Paper 07/11.

De Vita, Glauco, and Andrew Abbott. 2007. Do Exchange Rates Have any Impact upon UK Inward Foreign Direct Investment? Applied Economics 39: 2553-2564.

Egger, Peter, and Michael Pfaffermayr. 2004. Distance, Trade, and FDI: A Hausman-Taylor SUR Approach. Journal of Applied Econometrics 19(2): 227-246.

Eicher, Theo, Lindy Helfman, and Alex Lenkoski. 2011. Robust FDI Determinants: Bayesian Model Averaging in the Presence of Selection Bias. Working paper, University of Washington.

Greene, William H. 2003. Econometric Analysis: Fifth Edition. Upper Saddle River, NJ: Prentice Hall.

Hattari, Rabin, and Ramkishen S. Rajan. 2008. Sources of FDI Flows to Developing Asia: The Roles of Distance and Time Zones. ADB Institute Working Paper No. 117.

Head, Keith, Thierry Mayer, and John Ries. 2009. How Remote is the Offshoring Threat? European Economic Review 53: 429-444.

Head, Keith, Thierry Mayer and John Ries. 2010. The Erosion of Colonial Trade Linkages after Independence. Journal of International Economics, 81(1):1-14.

Horstmann, Ignatius, and James R. Markusen. 1992. Endogenous Market Structures in International Trade (natura facit saltum). Journal of International Economics, 32: 109-129.

Hummels, David. 2007. Transportation Costs and International Trade in the Second Era of Globalization. Journal of Economic Perspectives 21(3): 131-154.

Hummels, David, and Volodymyr Lugovsky. 2003. Usable Data? Matched Partner Trade Statistics as a Measure of International Transportation Costs. Department of Economics, Krannert School of Management, Purdue University.

Leamer, Edward and James Levishon. 1995. International Trade: The Evidence. G. M. Grossman and K. Rogoff, eds. Handbook of International Economics, V3. New York: Elsevier Publishing.

Limão, Nuno, and Anthony J. Venables. 2001. Infrastructure, Geographical Disadvantage, and Transport Costs. World Bank Economic Review 15(1): 451-479.

Marjit, SSugata. 2005. Trade Theory and the Role of Time Zones. Forthcoming, International Review of Economics and Finance.

Markusen, James R. and Anthony J. Venables. 1998. Multinational Firms and the New Trade Theory. Journal of International Economics, 46: 183-203.

Obstfeld, Maurice, and Kenneth Rogoff. 2000. The Six Major Puzzles in International Macroeconomics: Is There a Common Cause? NBER Macroeconomics Annual 15: 339-390.

Stein, Ernesto, and Christian Daude. 2007. Longitude Matters: Time Zones and the Location of Foreign Direct Investment. Journal of International Economics 71: 96-112.

Tinbergen, Jan. 1962. Shaping the World Economy: Suggestions for and International Economic Policy. New York: Twentieth Century Fund. 
Figure 1: Distance and the Strategy of the International Firm

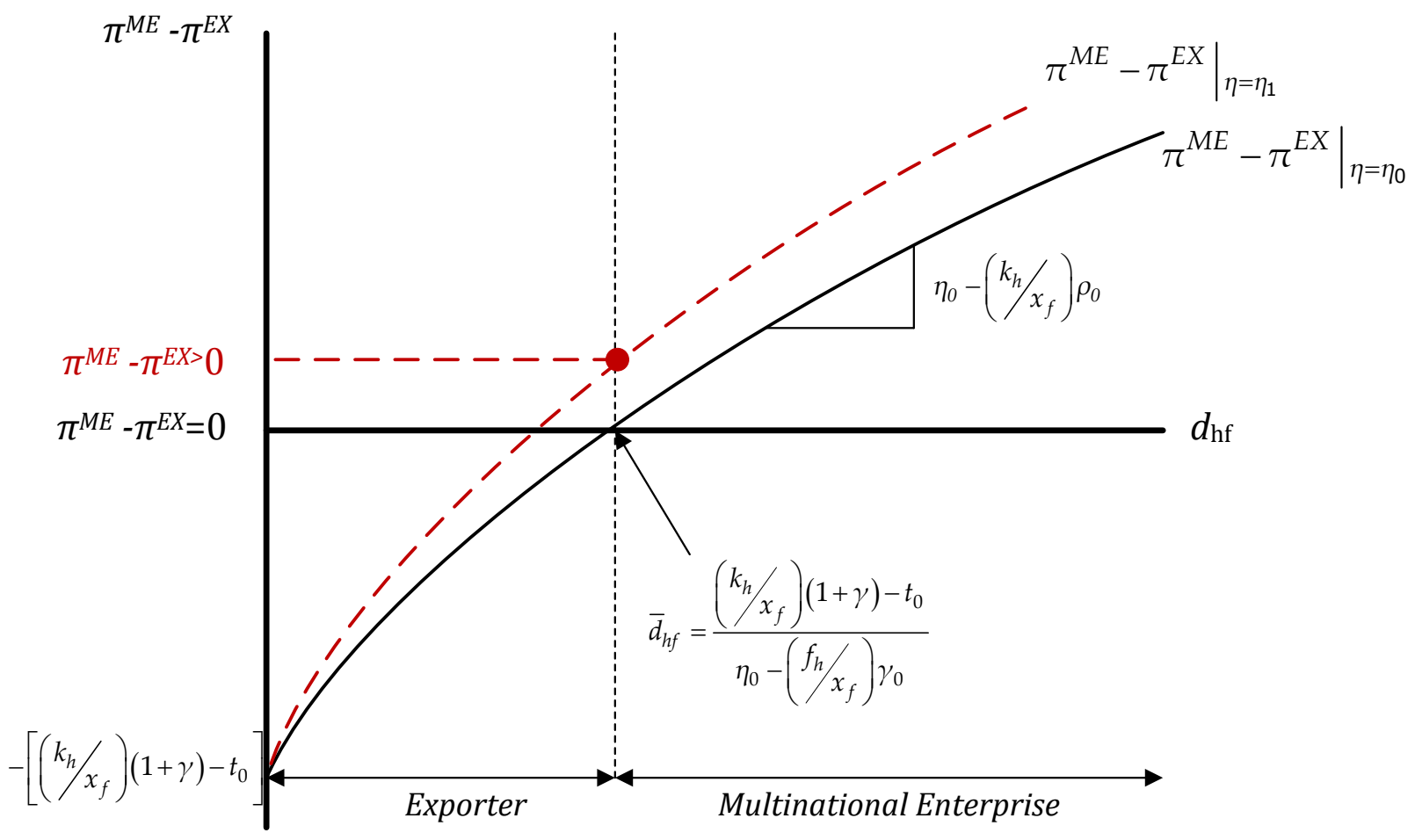

Figure 2: Baltic Dry Index, Jet Fuel Index, and Value-of-Shipment Weighted Average Real Values, Annual Observations, 1985-2010

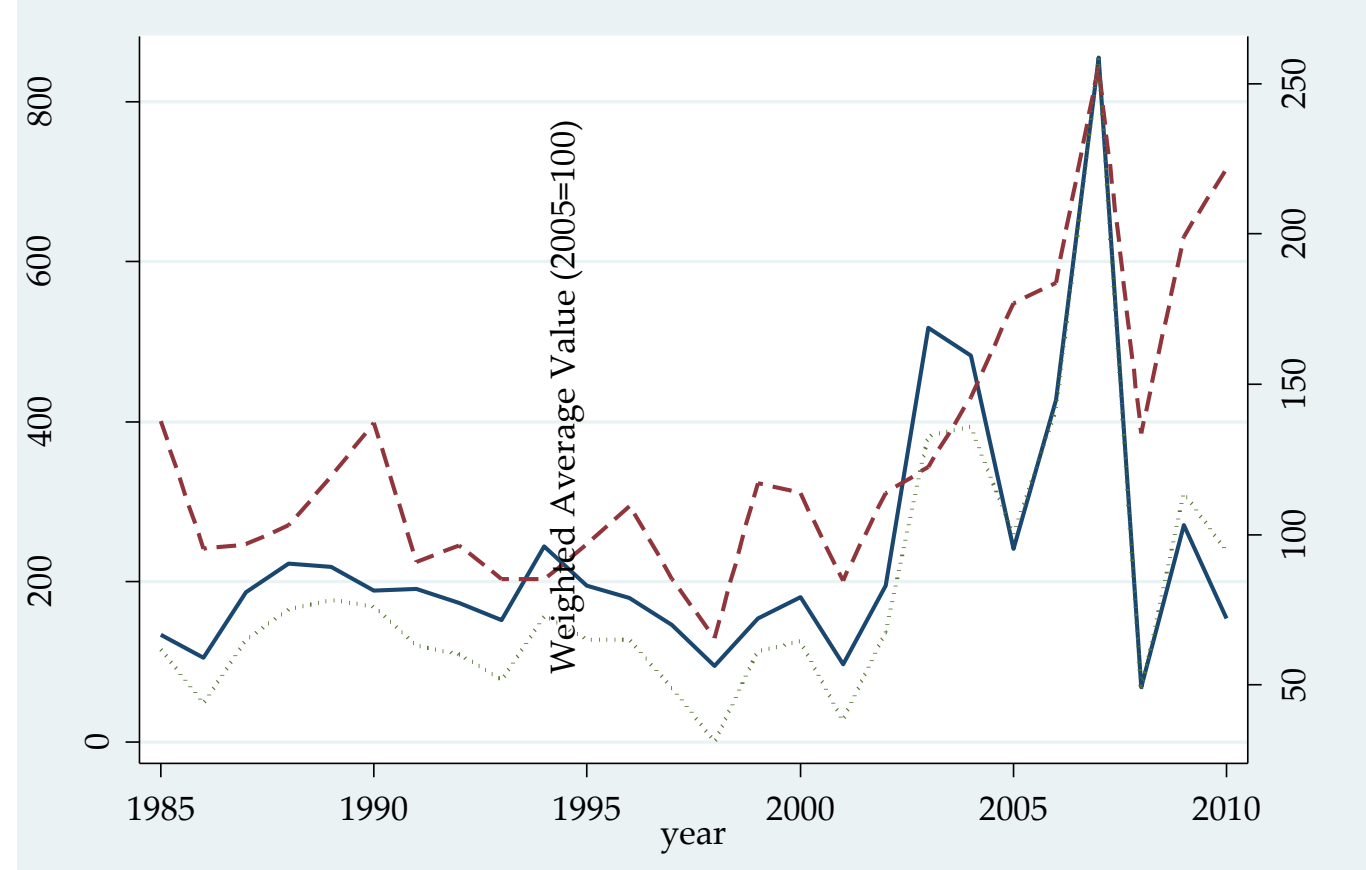

Baltic Dry --- Jet Fuel ……...... Weighted Average Value 


\section{Table 1: Countries Included}

\begin{tabular}{|c|c|}
\hline COUNTRY & COUNTRY \\
\hline Argentina & Japan \\
\hline Australia & Korea \\
\hline Austria & Luxembourg \\
\hline Belgium & Malaysia \\
\hline Brazil & Mexico \\
\hline Canada & Netherlands \\
\hline Chile & New Zealand \\
\hline China & Nigeria \\
\hline Columbia & Norway \\
\hline Costa Rica & Panama \\
\hline Czech Republic* & Peru \\
\hline Denmark & Philippines \\
\hline Ecuador & Poland* \\
\hline Egypt & Portugal \\
\hline Findland & Russia* \\
\hline France & Saudi Arabia \\
\hline Germany & Singapore \\
\hline Greece & South Africa \\
\hline Guatemala & Spain \\
\hline Honduras & Sweden \\
\hline Hong Kong & Switzerland \\
\hline Hungary* & Thailand \\
\hline India & Turkey \\
\hline Indonesia & UK \\
\hline Ireland & United Arab Emirates \\
\hline Israel & Venezuela \\
\hline Italy & \\
\hline
\end{tabular}

* Data begins in 1999. 
Table 2: Summary Statistics

\begin{tabular}{|c|c|c|c|c|c|c|}
\hline Variable & & Mean & Std. Dev. & Min & Max & Observations \\
\hline \multirow{3}{*}{ Total FDI Stock } & Overall & 23275.72 & 52514.24 & -396.096 & 494839.3 & $N=1302$ \\
\hline & Between & & 38351.04 & 212.8062 & 204815.9 & $\mathrm{n}=53$ \\
\hline & Within & & 35342.99 & -144814 & 377382.8 & $\overline{\mathrm{T}}=24.566$ \\
\hline \multirow{3}{*}{ Manufacturing FDI Stock } & Overall & & & & & $N=1272$ \\
\hline & Between & 5821.852 & 10303.77 & -275.99 & 84261.18 & $n=53$ \\
\hline & Within & & 9036.972 & 59.52009 & 48740.62 & $\overline{\mathrm{T}}=24$ \\
\hline \multirow{3}{*}{ Service FDI Stock } & Overall & & 4577.209 & -18871 & 41342.41 & $N=1259$ \\
\hline & Between & & & & & $\mathrm{n}=53$ \\
\hline & Within & 57.10334 & 171.5459 & -1.94824 & 2198.713 & $\overline{\mathrm{T}}=23.757$ \\
\hline \multirow{3}{*}{ Size Similarity } & Overall & & 126.6734 & 0.012168 & 836.8785 & $N=1361$ \\
\hline & Between & & 111.5277 & -696.245 & 1418.938 & $\mathrm{n}=53$ \\
\hline & Within & & & & & $\overline{\mathrm{T}}=25.679$ \\
\hline \multirow{3}{*}{ GDP Per Capita } & Overall & 0.096193 & 0.100472 & 0.003561 & 0.493062 & $N=1361$ \\
\hline & Between & & 0.099822 & 0.003906 & 0.404795 & $\mathrm{n}=53$ \\
\hline & Within & & 0.016376 & -0.04247 & 0.232917 & $\overline{\mathrm{T}}=25.679$ \\
\hline \multirow{3}{*}{ Population } & Overall & $77,800,000$ & $209,000,000$ & 367,200 & $1,340,000,000$ & $N=1378$ \\
\hline & Between & & $210,000,000$ & 425,495 & $1,220,000,000$ & $\mathrm{n}=$ \\
\hline & Within & & $21,400,000$ & $-129,000,000$ & $277,000,000$ & $T=$ \\
\hline \multirow{3}{*}{ Trade Openness } & Overall & 0.839 & 0.667 & 0.124 & 4.400 & $N=1362$ \\
\hline & Between & & 0.641 & 0.205 & 3.587 & $n=53$ \\
\hline & Within & & 0.196 & -0.097 & 2.254 & $\overline{\mathrm{T}}=25.698$ \\
\hline \multirow{3}{*}{ Private Credit \% of GDP } & Overall & 0.711 & 0.486 & 0.083 & 2.359 & $N=1351$ \\
\hline & Between & & 0.424 & 0.155 & 1.915 & $n=53$ \\
\hline & Within & & 0.247 & -0.133 & 2.057 & $\overline{\mathrm{T}}=25.491$ \\
\hline \multirow{3}{*}{$\begin{array}{l}\text { Phone Subscriptions Per } \\
1000\end{array}$} & Overall & 63.881 & 55.918 & 0.240 & 266.020 & $N=1378$ \\
\hline & Between & & 32.080 & 8.867 & 116.776 & $n=53$ \\
\hline & Within & & 46.004 & -18.623 & 248.478 & $T=$ \\
\hline \multirow{3}{*}{ Real Exchange Rate } & Overall & 0.391 & 0.456 & 0.000 & 2.719 & $N=1362$ \\
\hline & Between & & 0.370 & 0.000 & 1.625 & $\mathrm{n}=53$ \\
\hline & Within & & 0.273 & -0.155 & 2.703 & $\overline{\mathrm{T}}=25.698$ \\
\hline \multirow{3}{*}{ Hofstede Cultural Dist. } & Overall & 16.686 & 6.495 & 1.639 & 29.470 & $N=1378$ \\
\hline & Between & & 6.555 & 1.639 & 29.470 & $n=53$ \\
\hline & Within & & 0.000 & 16.686 & 16.686 & $T=$ \\
\hline \multirow{3}{*}{ Weighted Distance } & Overall & 8696.236 & 3450.512 & 2079.297 & 15535.870 & $N=1378$ \\
\hline & Between & & 3482.268 & 2079.297 & 15535.870 & $n=53$ \\
\hline & Within & & 0.000 & 8696.236 & 8696.236 & $T=$ \\
\hline \multirow{3}{*}{$\begin{array}{l}\text { Weighted-Average } \\
\text { Shipping Costs }\end{array}$} & Overall & 81.37013 & 45.59076 & 31.15153 & 258.5726 & $N=1378$ \\
\hline & Between & & 0 & 81.37013 & 81.37013 & $\mathrm{n}=53$ \\
\hline & Within & & 45.59076 & 31.15153 & 258.5726 & $\mathrm{~T}=$ \\
\hline
\end{tabular}


Table 3: Fixed-Effects Model and Hausman-Taylor Model Results 1985-2010

\begin{tabular}{|c|c|c|c|c|c|c|}
\hline & \multicolumn{2}{|c|}{ Total Stocks } & \multicolumn{2}{|c|}{ Manufacturing Stocks } & \multicolumn{2}{|c|}{ Service Stocks } \\
\hline & FEM & HTM & FEM & HTM & FEM & HTM \\
\hline \multirow[t]{2}{*}{ Size Similarity } & $6.573^{*}$ & $7.003^{* * *}$ & $14.01^{* * *}$ & $13.65^{\star * *}$ & $23.04^{* * *}$ & $23.75^{\star * *}$ \\
\hline & (3.477) & $(1.161)$ & (3.099) & $(1.357)$ & $(7.384)$ & (3.081) \\
\hline \multirow[t]{2}{*}{ GDP Per Capita } & $1.118^{\star *}$ & $1.043^{\star \star *}$ & 0.367 & $0.393^{\star *}$ & -0.222 & -0.316 \\
\hline & $(0.551)$ & $(0.153)$ & $(0.472)$ & $(0.179)$ & $(0.974)$ & $(0.413)$ \\
\hline \multirow[t]{2}{*}{ Population } & -0.401 & -0.124 & 0.164 & -0.0238 & $-4.208^{\star \star *}$ & $-3.636^{* * *}$ \\
\hline & $(0.611)$ & $(0.163)$ & (1.012) & $(0.201)$ & $(1.373)$ & $(0.484)$ \\
\hline \multirow[t]{2}{*}{ Trade Openness } & 0.577 & $0.556^{* * *}$ & 0.137 & $0.157^{*}$ & 0.397 & $0.367^{*}$ \\
\hline & $(0.364)$ & $(0.0745)$ & $(0.179)$ & $(0.0870)$ & $(0.494)$ & $(0.196)$ \\
\hline \multirow[t]{2}{*}{ Credit to Private Sector } & 0.177 & $0.194^{\star * *}$ & 0.151 & $0.144^{\star *}$ & 0.109 & 0.133 \\
\hline & $(0.125)$ & $(0.0569)$ & $(0.181)$ & $(0.0659)$ & $(0.204)$ & $(0.144)$ \\
\hline \multirow[t]{2}{*}{ Phone Subscriptions } & -0.0900 & -0.146 & $-0.794^{* *}$ & $-0.758^{* * *}$ & $-1.368^{\star *}$ & $-1.483^{* * *}$ \\
\hline & $(0.236)$ & $(0.143)$ & $(0.335)$ & $(0.164)$ & $(0.678)$ & $(0.402)$ \\
\hline \multirow[t]{2}{*}{ Real Exchange Rate } & 0.0207 & $0.0246^{* *}$ & 0.00140 & -0.00184 & 0.00673 & 0.0153 \\
\hline & $(0.0352)$ & $(0.0111)$ & $(0.0223)$ & $(0.0127)$ & $(0.0570)$ & $(0.0288)$ \\
\hline \multirow[t]{2}{*}{ Investment Treaty } & -0.178 & $-0.193^{* * *}$ & -0.267 & $-0.258^{\star * \star}$ & -0.413 & $-0.437^{\star *}$ \\
\hline & $(0.161)$ & $(0.0702)$ & $(0.254)$ & $(0.0808)$ & $(0.346)$ & $(0.201)$ \\
\hline \multirow[t]{2}{*}{ Trade Agreement } & 0.102 & 0.0952 & 0.151 & 0.161 & 0.204 & 0.179 \\
\hline & $(0.161)$ & $(0.0920)$ & $(0.225)$ & $(0.106)$ & $(0.330)$ & $(0.238)$ \\
\hline \multirow[t]{2}{*}{ Tax Treaty } & 0.111 & $0.103^{*}$ & 0.0690 & 0.0764 & $0.826^{* * *}$ & $0.802^{* * *}$ \\
\hline & $(0.169)$ & $(0.0578)$ & $(0.151)$ & $(0.0658)$ & $(0.253)$ & $(0.151)$ \\
\hline \multirow[t]{2}{*}{ Nafta } & 0.0807 & 0.0889 & -0.0995 & -0.108 & 0.0274 & 0.0427 \\
\hline & $(0.377)$ & $(0.123)$ & $(0.270)$ & $(0.140)$ & $(0.487)$ & $(0.313)$ \\
\hline \multirow[t]{2}{*}{ Shipping Costs $\times$ Distance } & $0.215^{\star *}$ & $0.205^{\star * *}$ & $0.157^{\star *}$ & $0.164^{\star * *}$ & 0.157 & 0.131 \\
\hline & $(0.0808)$ & $(0.0416)$ & $(0.0736)$ & $(0.0479)$ & $(0.177)$ & $(0.107)$ \\
\hline \multirow[t]{2}{*}{ Land Locked } & & -0.691 & & 0.307 & & -3.813 \\
\hline & & $(0.963)$ & & (1.331) & & $(4.702)$ \\
\hline \multirow[t]{2}{*}{ Distance } & & 0.681 & & -0.382 & & 4.546 \\
\hline & & $(0.842)$ & & $(1.038)$ & & (3.641) \\
\hline \multirow[t]{2}{*}{ Hofstede Index } & & 0.0130 & & -0.0278 & & 0.0611 \\
\hline & & $(0.0601)$ & & $(0.0863)$ & & $(0.276)$ \\
\hline \multirow[t]{2}{*}{ Adjacent } & & 3.287 & & 2.820 & & 17.59 \\
\hline & & (2.376) & & $(4.200)$ & & (13.96) \\
\hline \multirow[t]{2}{*}{ Constant } & 2.064 & -8.272 & -1.501 & 5.099 & $71.37^{\star *}$ & 20.59 \\
\hline & $(13.80)$ & (7.953) & $(17.65)$ & $(10.01)$ & $(27.98)$ & $(34.48)$ \\
\hline Observations & 1284 & 1284 & 1251 & 1251 & 1204 & 1204 \\
\hline Hausman Test & & 8.79 & & 2.81 & & 6.56 \\
\hline $\mathrm{F}$ & 116.11 & 138.95 & 48.30 & 72.96 & 54.46 & 30.59 \\
\hline Year Controls, Joint F & $10.82^{\star \star \star}$ & $5.94^{\star \star \star}$ & $8.54^{\star \star \star}$ & $5.75^{\star \star \star}$ & $5.91^{* * *}$ & $5.95^{\star \star \star}$ \\
\hline Cross Sections & 53 & 53 & 53 & 53 & 53 & 53 \\
\hline
\end{tabular}

Robust standard errors in parentheses, ${ }^{* * *} \mathrm{p}<0.01,{ }^{* *} \mathrm{p}<0.05,{ }^{*} \mathrm{p}<0.1$ 